Szydełko Joanna, Dąbrowska Izabela. Single nucleotide polymorphisms in adiponectin and its receptors' genes as potential risk factors for coronary artery disease in type 2 diabetes mellitus - an up-to-date overview. Journal of Education, Health and Sport. 2021;11(9):722-734. eISSN 2391-8306. DOI http://dx.doi.org/10.12775/JEHS.2021.11.09.087

https://apcz.umk.pl/JEHS/article/view/JEHS.2021.11.09.087

https://zenodo.org/record/5534087

The journal has had 5 points in Ministry of Science and Higher Education parametric evaluation. § 8. 2) and § 12. 1. 2) 22.02.2019. The Authors 2021

; Nicolaus Copernicus University in Torun, Poland

This article is published with open access at Licensee Open Journal Systems of Nicolaus Copernicus University in Torun, Poland
Open Access. This article is distributed under the terms of the Creative Commons Attribution Noncommercial License which permits any noncommercial use, distribution, and reproduction in any medium,

provided the original author (s) and source are credited. This is an open access article licensed under the terrss of the Creative Commons Attribution Non commercial license Share alike.
(http://creativecommons.org/licenses/by-nc-sa/4.0/) which permits unrestricted, non commercial use, distribution and reproduction in any medium, provided the work is properly cited.

The authors declare that there is no conflict of interests regarding the publication of this paper.

Received: 15.09.2021. Revised: 20.09.2021. Accepted: 27.09.2021.

\title{
Single nucleotide polymorphisms in adiponectin and its receptors' genes as potential risk factors for coronary artery disease in type 2 diabetes mellitus - an up-to-date overview
}

\author{
Joanna Szydełko' ${ }^{1 a}$, Izabela Dąbrowska ${ }^{2 b}$
}

${ }^{1}$ Department of Endocrinology, Diabetology and Metabolic Diseases, Medical University of Lublin, Poland

${ }^{2}$ Department of Interventional Radiology and Neuroradiology, Medical University of Lublin, Poland

a jszydelko@interia.pl, ORCID ID: https://orcid.org/0000-0003-3744-9058

bnematoda@gmail.com, ORCID: https://orcid.org/0000-0003-1593-2284

\section{Corresponding author:}

Joanna Szydełko

Department of Endocrinology, Diabetology and Metabolic Diseases

Jaczewskiego 8 Street

20-954 Lublin, Poland

phone: +48817244668

e-mail: jszydelko@interia.pl 


\begin{abstract}
Introduction: Type 2 diabetes mellitus (T2DM) is a chronic metabolic disease with still growing incidence among adults and young people worldwide. Patients with T2DM are more susceptible to develop coronary artery disease (CAD) than non-diabetic individuals. Several pre-clinical and clinical studies suggested that adiponectin, a pleiotropic hormone with antiatherogenic, anti-inflammatory, and insulin-sensitizing properties, may be a molecular link between metabolic and cardiovascular diseases.
\end{abstract}

Aim of the study: This article summarizes the current knowledge on single nucleotide polymorphisms (SNPs) within the adiponectin and its receptors' genes on the risk of CAD in patients with T2DM.

Description of knowledge: Adiponectin, the most abundant circulating adipocytokine, is encoded by the Acrp30/adiponectin gene on chromosome 3q27, which constitutes a region specific for obesity-related metabolic syndrome. A genetic deficit of this adipokine may be responsible for the increased risk of CAD both in the general population and T2DM subjects. The results of recent years' studies highlight that SNPs at the adiponectin locus, $+45 \mathrm{~T}>\mathrm{G}$ and $+276 \mathrm{G}>\mathrm{T}$ as well within its two receptors, are determinants of early onset atherosclerosis in individuals with T2DM.

Conclusions: SNPs in ADIPOQ, ADIPOR1 and ADIPOR2 may modify the risk of CAD in the group of patients with T2DM. SNP +45 and SNP +276 seem to be attractive, molecular markers for identification of diabetic individuals at especially high risk of CAD. The discovering of their exact mechanisms may result in novel screening options as well as diagnostic process and treatment scheme. Therefore, further research is required to determine the effects of adiponectin and its receptors' polymorphisms and their roles in the pathogenesis of obesity-related metabolic diseases.

Key words: adiponectin; AdipoR1; AdipoR2; type 2 diabetes mellitus; coronary artery disease; single nucleotide polymorphisms

\title{
Introduction
}

Type 2 diabetes mellitus (T2DM) is a chronic metabolic disease characterized by hyperglycemia that results from a progressive beta-cell impairment, insulin secretion deficiency and concomitant insulin resistance [1]. The prevalence of diabetes mellitus has 
been growing at an alarming rate over the past decades [2]. According to the latest epidemiological reports, T2DM has reached global epidemic proportions and it is one of the major public health challenges in the twenty-first century $[3,4]$.

Patients with T2DM are at increased risk of development of cardiovascular diseases and associated clinical complications [5]. It is estimated that the incidence of coronary artery disease (CAD) is two to four times more frequent in diabetic patients than in non-diabetic individuals, representing the leading cause of mortality and morbidity in this population [6-8]. The mechanisms involved in the initiation of CAD in T2DM seem to be a combination of various genetic, molecular, and environmental factors [9-10]. Chronically elevated glucose level coexisting with dyslipidemia, especially increased levels of atherogenic low-density lipoprotein (LDL), oxidative stress, and increased inflammation are tightly involved in the pathogenesis of atherosclerosis at almost every step of the atherogenic process [11]. It is widely known that increased susceptibility to atherosclerosis results from unbalanced activity of pro- and anti-atherogenic factors, which are both environmental and genetic in origin [12].

Adiponectin, also known as adipocyte complement-related protein of $30 \mathrm{kDa}$ (Acrp30), AdipoQ, apM1, gelatin binding protein of $28 \mathrm{kD}$ (GBP-28), structurally belonging to $\mathrm{C} 1 \mathrm{q} / \mathrm{TNF}$ protein family, is one of anti-atherogenic and anti-inflammatory molecules with insulin-sensitizing properties that has recently draw much interest among researchers $[13,14]$. This highly bioactive adipocyte-derived adipocytokine acts not only locally in adipose tissue in an autocrine and paracrine manner, but it also circulates in the bloodstream, and thus it regulates processes in other tissues and distant organs $[15,16]$. What is more, adiponectin exerts its pleiotropic influence on glucose homeostasis, insulin sensitivity, lipid metabolism, and vascular endothelium integrity via two transmembrane receptors, called adiponectin receptor 1 (AdipoR1) and adiponectin receptor 2 (AdipoR2) [15-17].

The results of recent years' studies have revealed low plasma/serum adiponectin level both in T2DM and CAD [18]. It is suggested that single nucleotide polymorphisms (SNPs) in adiponectin and its receptors, AdipoR1, AdipoR2, genes are associated with increased risk of CAD in patients with T2DM, although the link between hypoadiponectinemia and adiponectin gene variants remains still unclear $[19,20]$. A thorough understanding of abovementioned associations and gene-adipose tissue microenvironment interactions will likely result in innovative approach to diagnostic process and rationalizing treatment methods of these highly prevalent diseases in the future. 


\section{Aim of the study}

The aim of this systematic review was to present the potential role of SNPs within the adiponectin and its receptors' genes on the risk of CAD in patients with T2DM. Moreover, we also discussed the relationship between adiponectin gene polymorphisms and serum/plasma adiponectin level.

\section{Materials and methods}

The available literature was subjectively selected due to its usefulness in showing genetic influence of the adiponectin, AdipoR1 and AdipoR2 genes polymorphisms in the development of CAD among patients with T2DM. Furthermore, selected SNPs in these genes as promising diagnostic and/or prognostic tools for CAD were evaluated. Data which reveals inconsistency in results was shown as well. Articles in English in the EBSCO and the PubMed database have been analyzed using key words in various combinations: 'single nucleotide polymorphisms', 'genetic markers' 'adiponectin', 'AdipoR1', 'AdipoR2', 'type 2 diabetes mellitus', and 'coronary artery disease'.

\section{Adiponectin in type 2 diabetes mellitus and coronary artery disease - genetic background}

A growing number of pre-clinical and clinical studies have demonstrated that the development of CAD in patients with T2DM is usually initiated many years before the diagnosis of diabetes mellitus, due to the common association of glucose intolerance with the components of metabolic syndrome, including obesity, hypertension, dyslipidemia, and insulin resistance [21]. What is interesting, but not widely known it is hypothesized that T2DM and CAD share a common genetic background, and the adiponectin signaling-related gene is postulated to play crucial roles in these molecular pathways [22,23]. A genetic deficit of this adipocytokine may be responsible for the increased risk of CAD both in the general population and T2DM subjects. In support of this hypothesis is the recent finding that human recombinant adiponectin suppresses endothelial adhesion molecule expression, vascular smooth muscle cell proliferation, and macrophage to foam cell transformation as well as tumour necrosis factor $\alpha(\mathrm{TNF}-\alpha)$ production by macrophages in vitro $[24,25]$.

Adiponectin, a 244 amino acids protein, is encoded by the APM1 gene located on the long arm of the third chromosome (locus 3q27), a genomic region identified as a susceptibility locus for the metabolic syndrome, T2DM and CAD [14]. The gene is $17 \mathrm{~kb}$ long and consists of three exons and two introns, basically regulated by peroxisome proliferatoractivated receptors gamma (PPAR- $\gamma$ ), C-EBP, and ADDL, which are key transcription factors in adipogenesis [26]. Structurally, adiponectin consists of four domains: N-terminal signal 
sequence, variable region, collagen-type domain, and C-terminal globular domain. In addition, adiponectin is one of the hormones with the highest plasma concentrations, and it circulates in the bloodstream in three major multimeric forms, which include low molecular weight (LMW) trimers, middle molecular weight (MMW) hexamers, and high molecular weight (HMW) multimers, which is suggested to be the most active form $[14,15,26]$.

Adiponectin mediates its effects by two main receptors, AdipoR1 and AdipoR2 [26]. The human ADIPOR1 gene is located at chromosome 1p36.13-q41, whereas ADIPOR2 gene is located on chromosomal locus 12p13.33 [20,27]. AdipoR1 is primarily expressed in skeletal muscle and activated by AMPK (AMP-dependent protein kinase) phosphorylation, and AdipoR2 is mainly localized in liver and involved in the activation of peroxisome proliferator activating receptor alpha (PPAR- $\alpha$ ) [14]. These receptors are integral membrane proteins with seven transmembrane domains, similar to the family of $G$ protein-coupled receptors, although, in contrary to them, adiponectin receptors have an internal N-terminal portion and eternal C-terminal domain [26].

According to the latest studies in many populations, several SNPs in ADIPOQ, ADIPOR1 and ADIPOR2 genes are associated with increased susceptibility to CAD development in patients with T2DM [19,20,27,29-39].

\section{SNPs in ADIPOQ gene related to coronary artery disease in type 2 diabetes mellitus}

SNPs, in addition to insertions and deletions, are among the three types of DNA sequence variations. They occur when only one nucleotide in the DNA sequence changes, with a usual alternative of two possible nucleotides on a given position. What is more, to identify a polymorphism, the variation must occur at least on $1 \%$ of the general population, and those polymorphisms that affect the coding or regulatory sequence and that produce important changes within the protein structure or the expression mechanism appear as different phenotypes [28].

Based on the literature data, two SNPs at the adiponectin locus, $+45 \mathrm{~T}>\mathrm{G}$ (rs2241766) in exon 2 and $+276 \mathrm{G}>\mathrm{T}$ (rs1501299) in intron 2, have been recently investigated as determinants of CAD risk in individuals with T2DM [19,29-35]. Some authors proved that susceptibility for CAD due to SNP +45 was independent of classic cardiovascular risk factors [29]. Mohammadzadeh $G$ et al. in the clinical study indicated that not only GT and TT genotypes, but also $\mathrm{T}$ allele of SNP $+276 \mathrm{G}>\mathrm{T}$ were related to an increased risk of CAD $[34,35]$. However, researchers did not find any significant association between the SNP +45 $\mathrm{T}>\mathrm{G}$ and $\mathrm{CAD}$ in diabetic individuals which stands in contrary to several previous reports [29-31,33]. 
Despite serum/plasma adiponectin concentrations are highly hereditable and are linked to ADIPOQ gene, there are only single studies evaluating the correlations between selected SNPs in the ADIPOQ gene and circulating levels of total adiponectin and its isoforms $[19,31,32,34,36]$. It is worth to underline that only the study conducted by Oliveira $C S$ et al. showed that $\mathrm{SNP}+45 \mathrm{~T}>\mathrm{G}$ was associated with total and HMW adiponectin levels, while SNP-11391 G>A was correlated with HMW adiponectin levels [32]. In turn, Tong $G$ et al. have demonstrated that three genetic variants, such as $-11377 \mathrm{C}>\mathrm{G},-10066 \mathrm{G}>\mathrm{A}$, and $+276 \mathrm{G}>\mathrm{T}$ were associated with plasma adiponectin level, with the strongest effect for -11377 $\mathrm{C}>\mathrm{G}$ and $+276 \mathrm{G}>\mathrm{T}$ [36]. Moreover, some authors displayed that diabetic patients with $\mathrm{CAD}$ had more lower serum levels of adiponectin than those without CAD, but they found that different genotypes of $\mathrm{SNP}+45 \mathrm{~T}>\mathrm{G}$ and $+276 \mathrm{G}>\mathrm{T}$ were not significantly related to adiponectin concentrations [34,35].

The data about SNPs that are linked to cardiovascular risk in T2DM is limited and have been inconsistent. Therefore, in table 1 we attempted to summarize the most common SNPs in adiponectin and its receptor genes associated with increased risk of CAD in patients with T2DM as well their correlations with serum/plasma adiponectin levels [Table 1].

\section{SNPs in ADIPOR1 and ADIPOR2 genes related to coronary artery disease in type 2 diabetes mellitus}

Currently, there is no concrete evidence for the association between SNPs of ADIPOR1 and CAD in diabetic individuals [20,27,37,38]. It is suggested that some genetic variants in ADIPOR1, such as rs7539542, rs10920531, rs4950894, rs3737884, rs16850797, and rs7514221 may be potentially engaged in the pathogenesis and increased susceptibility of CAD in T2DM, but further studies are necessary to evaluate their real clinical roles [Table 1].

Associations between ADIPOR2 gene variants with T2DM and CAD as well as another components of obesity-linked metabolic syndrome have been reported in several human populations $[27,39,40]$. The results of the Finnish Diabetes Prevention Study indicated that independent genetic signals in ADIPOR2 locus contribute to the risk of cardiovascular diseases and T2DM in individuals with impaired glucose tolerance. What is more, researchers revealed that rs11061937 and rs1058322 were significantly associated with cardiovascular disturbances, whereas subjects homozygous for the rare minor alleles of rs11061946 and rs 11061973 had increased risk of converting from IGT to T2DM [27]. However, so far there is no study evaluating SNPs of ADIPOR2 as markers of increased CAD in the group of diabetic patients. 
Table 1. Characteristics of SNPs in adiponectin and its receptor genes associated with increased risk of coronary artery disease in patients with type 2 diabetes mellitus.

\begin{tabular}{|c|c|c|c|c|c|c|}
\hline $\begin{array}{c}\text { Authors, Year } \\
\text { [Reference] }\end{array}$ & Ethnicity & $\begin{array}{l}\text { Study Group vs. Control Group } \\
\text { T2DM with CAD vs. T2DM without CAD }\end{array}$ & SNPs & $\begin{array}{l}\text { Adiponectin/ } \\
\text { AdipoR1 gene }\end{array}$ & Genotyping Method & $\begin{array}{c}\text { Correlation with } \\
\text { serum/plasma adiponectin }\end{array}$ \\
\hline $\begin{array}{l}\text { Bacci S et al., } \\
2004[19]\end{array}$ & $\begin{array}{l}\text { Europe } \\
\text { (Italian) }\end{array}$ & $n=142$ vs. $n=234$ & $\mathrm{SNP}+276(\mathrm{G}>\mathrm{T})$ & adiponectin gene & $\begin{array}{l}\text { PCR followed by dot } \\
\text { blotting and allele- } \\
\text { specific hybridization }\end{array}$ & $\begin{array}{c}\text { serum adiponectin level did not } \\
\text { correlate with SNPs at }+276 \\
\text { loci of adiponectin gene }\end{array}$ \\
\hline $\begin{array}{l}\text { Lacquemant } C \text { et } \\
\text { al., } 2004 \text { [29] }\end{array}$ & $\begin{array}{l}\text { Caucasian/Europe } \\
\text { (French and } \\
\text { Swiss) }\end{array}$ & $n=162$ vs. $n=315$ & $\mathrm{SNP}+45(\mathrm{~T}>\mathrm{G})$ & adiponectin gene & $\begin{array}{c}\text { PCR-DS or } \\
\text { LightCycler }{ }^{\mathrm{TM}} \text { technology }\end{array}$ & not examined \\
\hline $\begin{array}{l}\text { Al-Daghri NM et } \\
\text { al., 2011 [30] }\end{array}$ & $\begin{array}{c}\text { South Asia } \\
\text { (Saudi Arabia) }\end{array}$ & $n=123$ vs. $n=295$ & $\mathrm{SNP}+45(\mathrm{~T}>\mathrm{G})$ & adiponectin gene & PCR-RFLP & not examined \\
\hline $\begin{array}{l}\text { Esteghamati A et } \\
\text { al., } 2012[31]\end{array}$ & $\begin{array}{l}\text { West Asia } \\
\text { (Iranian) }\end{array}$ & $n=114$ vs. $n=127$ & $\mathrm{SNP}+45(\mathrm{~T}>\mathrm{G})$ & adiponectin gene & PCR-RFLP & $\begin{array}{l}\text { serum adiponectin level did not } \\
\text { correlate with SNPs at }+45 \text { and } \\
+276 \text { loci of adiponectin gene }\end{array}$ \\
\hline $\begin{array}{l}\text { Oliveira CS et } \\
\text { al., } 2012[32]\end{array}$ & $\begin{array}{c}\text { America } \\
\text { (African, } \\
\text { Amerindian, } \\
\text { Asian, European } \\
\text { Caucasian of } \\
\text { several different } \\
\text { countries of origin } \\
\text { reflecting the } \\
\text { Brazilian } \\
\text { population) }\end{array}$ & $n=225$ vs. $n=70$ & $\begin{array}{l}\mathrm{SNP}+45(\mathrm{~T}>\mathrm{G}) \\
\mathrm{SNP}+276(\mathrm{G}>\mathrm{T})\end{array}$ & adiponectin gene & $\begin{array}{l}\text { ABD kits from Applied } \\
\text { Biosystems }\end{array}$ & $\begin{array}{c}\text { plasma total and HMW } \\
\text { adiponectin levels correlated } \\
\text { with } \mathrm{SNP}+45(\mathrm{~T}>\mathrm{G}) \text {, while } \\
\text { SNP-11391 }(\mathrm{G}>\mathrm{A}) \text { was } \\
\text { associated with HMW } \\
\text { adiponectin level }\end{array}$ \\
\hline $\begin{array}{l}\text { Tong G et al., } \\
2013[36]\end{array}$ & $\begin{array}{l}\text { East Asia } \\
\text { (Chinese) }\end{array}$ & $n=560$ vs. $n=550$ & $\begin{array}{l}\mathrm{SNP}-11377 \\
\quad(\mathrm{C}>\mathrm{G})\end{array}$ & adiponectin gene & Taqman technology & $\begin{array}{c}\text { plasma adiponectin level } \\
\text { correlated with SNPs at - } \\
11377(\mathrm{C}>\mathrm{G}),-10066(\mathrm{G}>\mathrm{A}), \\
\text { and }+276(\mathrm{G}>\mathrm{T}) \text { with the } \\
\text { strongest effect for }-11377 \\
(\mathrm{C}>\mathrm{G}) \text { and }+276(\mathrm{G}>\mathrm{T})\end{array}$ \\
\hline $\begin{array}{c}\text { Mofarrah M et } \\
\text { al., } 2016[33]\end{array}$ & $\begin{array}{l}\text { West Asia } \\
\text { (Iranian) }\end{array}$ & $n=152$ vs. $n=72$ & $\mathrm{SNP}+45(\mathrm{~T}>\mathrm{G})$ & adiponectin gene & HRM analysis & not examined \\
\hline $\begin{array}{c}\text { Mohammadzadeh } \\
\text { G et al., } 2016 \\
{[34]}\end{array}$ & $\begin{array}{l}\text { West Asia } \\
\text { (Iranian) }\end{array}$ & $n=100$ vs. $n=100$ & $\mathrm{SNP}+276(\mathrm{G}>\mathrm{T})$ & adiponectin gene & PCR-RFLP & $\begin{array}{l}\text { serum adiponectin level did not } \\
\text { correlate with SNPs at }+45 \text { and } \\
+276 \text { loci of adiponectin gene }\end{array}$ \\
\hline Soccio T et al., & Caucasian/Europe, & $n=426$ vs. $n=518$ & rs 7539542, & AdipoR1 & PCR followed by & not examined \\
\hline
\end{tabular}




\begin{tabular}{|c|c|c|c|c|c|c|}
\hline 2006 [37] & $\begin{array}{c}\text { America } \\
\text { (Italian, Boston) }\end{array}$ & & $\begin{array}{l}\text { rs10920531, } \\
\text { rs4950894 }\end{array}$ & & $\begin{array}{c}\text { SBE/fluorescence } \\
\text { polarization, Taqman } \\
\text { technology }\end{array}$ & \\
\hline $\begin{array}{c}\text { Jin Z et al., } 2014 \\
{[38]}\end{array}$ & $\begin{array}{l}\text { East Asia } \\
\text { (Chinese) }\end{array}$ & $n=174$ vs. $n=165^{*}$ & $\begin{array}{l}\text { rs3737884 } \\
(\mathrm{C}>\mathrm{T}) \\
\mathrm{rs} 16850797 \\
(\mathrm{G}>\mathrm{C})^{* *}\end{array}$ & AdipoR1 & $\begin{array}{c}\text { HRM analysis, PCR- } \\
\text { RFLP }\end{array}$ & not examined \\
\hline $\begin{array}{l}\text { Wang F et al., } \\
2016 \text { [20] }\end{array}$ & $\begin{array}{l}\text { East Asia } \\
\text { (Chinese) }\end{array}$ & $n=302$ vs. $n=295^{* * *}$ & $\begin{array}{c}\text { rs3737884-G, } \\
\text { rs7514221- } \\
\mathrm{C}^{* * * *}\end{array}$ & AdipoR1 & $\begin{array}{l}\text { PCR-RFLP, HRM } \\
\text { analysis }\end{array}$ & not examined \\
\hline
\end{tabular}

*173 subjects with CAD and 145 healthy controls were also analyzed in the study. ** rs3737884-G was simultaneously associated with an increased risk of T2D, CAD, and T2D+CAD, and 16850797-C was separately associated with T2D and T2D+CAD. ***316 subjects with CAD and 268 healthy controls were also analyzed in the study. ****rs3737884-G and rs7514221-C were associated with an increased susceptibility to CAD, T2D, and T2D+CAD. rs16850797-C was associated with T2D and T2D+CAD. T2DM - type 2 diabetes mellitus; CAD - coronary artery disease; SNP - single nucleotide polymorphism; AdipoR1 - adiponectin receptor 1; RefSNP or rs - Reference SNP; HMW - high molecular weight; PCR - Polymerase Chain Reaction; PCR-DS - Polymerase Chain Reaction-direct sequencing; PCR-RFLP - Polymerase Chain ReactionRestriction Fragment Length Polymorphism; ABD - Assay by Design; HRM - High Resolution Melt; SBE - single-base extension; SNP+45 $(\mathrm{T}>\mathrm{G})=\mathrm{rs} 2241766 ; \mathrm{SNP}+276(\mathrm{G}>\mathrm{T})=\operatorname{rs} 1501299 ; \mathrm{SNP}-11377(\mathrm{C}>\mathrm{G})=\mathrm{rs} 266729 ; \mathrm{SNP}-10066(\mathrm{G}>\mathrm{A})=\mathrm{rs} 182052 ; \mathrm{SNP}-11391(\mathrm{G}>\mathrm{A})=$ rs 17300539 


\section{Conclusions}

To conclude, it is worth to emphasize that SNPs in ADIPOQ, ADIPOR1 and ADIPOR2 may modify the risk of CAD in the group of patients with T2DM. SNP +45 and SNP +276 seem to be attractive, molecular markers for identification of diabetic individuals at especially high risk of CAD. The discovering of their exact mechanisms may result in novel screening options as well as diagnostic process and treatment scheme. Therefore, further research is required to determine the effects of adiponectin and its receptors' polymorphisms and their roles in the pathogenesis of obesity-related metabolic diseases.

\section{References:}

1. Stumvoll M, Goldstein BJ, van Haeften TW. Type 2 diabetes: principles of pathogenesis and therapy. Lancet. 2005;365(9467):1333-1346. doi: 10.1016/S0140-6736(05)61032-X.

2. Lascar N, Brown J, Pattison H, Barnett AH, Bailey CJ, Bellary S. Type 2 diabetes in adolescents and young adults. Lancet Diabetes Endocrinol. 2018;6(1):69-80. doi: $10.1016 / \mathrm{S} 2213-8587(17) 30186-9$.

3. Nolan CJ, Damm P, Prentki M. Type 2 diabetes across generations: from pathophysiology to prevention and management. Lancet. 2011;378(9786):169-181. doi: 10.1016/S01406736(11)60614-4.

4. Zheng Y, Ley SH, Hu FB. Global aetiology and epidemiology of type 2 diabetes mellitus and its complications. Nat Rev Endocrinol. 2018;14(2):88-98. doi: 10.1038/nrendo.2017.151.

5. Vaidya V, Gangan N, Sheehan J. Impact of cardiovascular complications among patients with Type 2 diabetes mellitus: a systematic review. Expert Rev Pharmacoecon Outcomes Res. 2015;15(3):487-497. doi: 10.1586/14737167.2015.1024661.

6. van Dieren S, Beulens JW, van der Schouw YT, Grobbee DE, Neal B. The global burden of diabetes and its complications: an emerging pandemic. Eur J Cardiovasc Prev Rehabil. 2010;17 Suppl 1:S3-8. doi: 10.1097/01.hjr.0000368191.86614.5a.

7. Norhammar A, Schenck-Gustafsson K. Type 2 diabetes and cardiovascular disease in women. Diabetologia. 2013;56(1):1-9. doi: 10.1007/s00125-012-2694-y.

8. Lam T, Burns K, Dennis M, Cheung NW, Gunton JE. Assessment of cardiovascular risk in diabetes: Risk scores and provocative testing. World J Diabetes. 2015;6(4):634-641. doi: 10.4239/wjd.v6.i4.634.

9. Glovaci D, Fan W, Wong ND. Epidemiology of Diabetes Mellitus and Cardiovascular Disease. Curr Cardiol Rep. 2019;21(4):21. doi: 10.1007/s11886-019-1107-y. 
10. McGurnaghan S, Blackbourn LAK, Mocevic E, Haagen Panton U, McCrimmon RJ, Sattar N, et al. Cardiovascular disease prevalence and risk factor prevalence in Type 2 diabetes: a contemporary analysis. Diabet Med. 2019;36(6):718-725. doi: 10.1111/dme.13825.

11. Poznyak A, Grechko AV, Poggio P, Myasoedova VA, Alfieri V, Orekhov AN. The Diabetes Mellitus-Atherosclerosis Connection: The Role of Lipid and Glucose Metabolism and Chronic Inflammation. Int J Mol Sci. 2020;21(5):1835. doi: 10.3390/ijms21051835.

12. Tedgui A, Mallat Z. Anti-inflammatory mechanisms in the vascular wall. Circ Res. 2001;88(9):877-887. doi: 10.1161/hh0901.090440.

13. Yamauchi T, Hara K, Kubota N, Terauchi Y, Tobe K, Froguel P, et al. Dual roles of adiponectin/Acrp30 in vivo as an anti-diabetic and anti-atherogenic adipokine. Curr Drug Targets Immune Endocr Metabol Disord. 2003;3(4):243-254. doi: $10.2174 / 1568008033340090$.

14. Shehzad A, Iqbal W, Shehzad O, Lee YS. Adiponectin: regulation of its production and its role in human diseases. Hormones (Athens). 2012;11(1):8-20. doi:10.1007/BF03401534.

15. Szydełko J, Trojanowska P, Dąbrowska I, Szydełko-Gorzkowicz M, Litwińczuk M. Adiponectin as novel biomarker of endothelial dysfunction in insulin resistance and obesity - a narrative review. J. Educ. Health Sport. 2020;10(9):591-606. doi: 10.12775/JEHS.2020.10.09.071.

16. Wang ZV, Scherer PE. Adiponectin, the past two decades. J Mol Cell Biol. 2016;8(2):93100. doi: 10.1093/jmcb/mjw011.

17. Yamauchi T, Kamon J, Ito $\mathrm{Y}$, Tsuchida A, Yokomizo $\mathrm{T}$, Kita $\mathrm{S}$, et al. Cloning of adiponectin receptors that mediate antidiabetic metabolic effects. Nature. 2003;423(6941):762-769. doi: 10.1038/nature01705.

18. Mohammadzadeh G, Ghaffari MA. Additional effect of diabetes mellitus type 2 on the risk of coronary artery disease: role of serum adiponectin. Iran Red Crescent Med J. 2014;16(1):e8742. doi: 10.5812/ircmj.8742.

19. Bacci S, Menzaghi C, Ercolino T, Ma X, Rauseo A, Salvemini L, et al. The +276 G/T single nucleotide polymorphism of the adiponectin gene is associated with coronary artery disease in type 2 diabetic patients. Diabetes Care. 2004;27(8):2015-2020. doi: 10.2337/diacare.27.8.2015. 
20. Wang F, Suo S, Sun L, Yang J, Yang F, Zhao C, et al. Analysis of the Relationship Between ADIPOR1 Variants and the Susceptibility of Chronic Metabolic Diseases in a Northeast Han Chinese Population. Genet Test Mol Biomarkers. 2016;20(2):81-85. doi: 10.1089/gtmb.2015.0148.

21. Sheikh-Ali M, Raheja P, Borja-Hart N. Medical management and strategies to prevent coronary artery disease in patients with type 2 diabetes mellitus. Postgrad Med. 2013;125(1):17-33. doi: 10.3810/pgm.2013.01.2621.

22. Dong C, Tang L, Liu Z, Bu S, Liu Q, Wang Q, et al. Landscape of the relationship between type 2 diabetes and coronary heart disease through an integrated gene network analysis. Gene. 2014;539(1):30-36. doi: 10.1016/j.gene.2014.02.001.

23. Tao C, Sifuentes A, Holland WL. Regulation of glucose and lipid homeostasis by adiponectin: effects on hepatocytes, pancreatic $\beta$ cells and adipocytes. Best Pract Res Clin Endocrinol Metab. 2014;28(1):43-58. doi: 10.1016/j.beem.2013.11.003.

24. Arita Y, Kihara S, Ouchi N, Maeda K, Kuriyama H, Okamoto Y, et al. Adipocytederived plasma protein adiponectin acts as a platelet-derived growth factor-BB-binding protein and regulates growth factor-induced common postreceptor signal in vascular smooth muscle cell. Circulation. 2002;105(24):2893-2898. doi: 10.1161/01.cir.0000018622.84402.ff.

25. Yokota T, Oritani K, Takahashi I, Ishikawa J, Matsuyama A, Ouchi N, et al. Adiponectin, a new member of the family of soluble defense collagens, negatively regulates the growth of myelomonocytic progenitors and the functions of macrophages. Blood. 2000;96(5):1723-1732.

26. Bermúdez VJ, Rojas E, Toledo A, Rodríguez-Molina D, Vega K, Suárez L, et al. Singlenucleotide polymorphisms in adiponectin, AdipoR1, and AdipoR2 genes: insulin resistance and type 2 diabetes mellitus candidate genes. Am J Ther. 2013;20(4):414-421. doi: 10.1097/MJT.0b013e318235f206.

27. Siitonen N, Pulkkinen L, Lindström J, Kolehmainen M, Schwab U, Eriksson JG, et al. Association of ADIPOR2 gene variants with cardiovascular disease and type 2 diabetes risk in individuals with impaired glucose tolerance: the Finnish Diabetes Prevention Study. Cardiovasc Diabetol. 2011;10:83. doi: 10.1186/1475-2840-10-83.

28. Vignal A, Milan D, SanCristobal M, Eggen A. A review on SNP and other types of molecular markers and their use in animal genetics. Genet Sel Evol. 2002;34(3):275-305. doi: 10.1186/1297-9686-34-3-275. 
29. Lacquemant $C$, Froguel $P$, Lobbens $S$, Izzo P, Dina $C$, Ruiz J. The adiponectin gene $\mathrm{SNP}+45$ is associated with coronary artery disease in Type 2 (non-insulin-dependent) diabetes mellitus. Diabet Med. 2004;21(7):776-781. doi: 10.1111/j.14645491.2004.01224.x.

30. Al-Daghri NM, Al-Attas OS, Alokail MS, Alkharfy KM, Hussain T. Adiponectin gene variants and the risk of coronary artery disease in patients with type 2 diabetes. Mol Biol Rep. 2011;38(6):3703-3708. doi: 10.1007/s11033-010-0484-5.

31. Esteghamati A, Mansournia N, Nakhjavani M, Mansournia MA, Nikzamir A, Abbasi M. Association of $+45(\mathrm{~T} / \mathrm{G})$ and $+276(\mathrm{G} / \mathrm{T})$ polymorphisms in the adiponectin gene with coronary artery disease in a population of Iranian patients with type 2 diabetes. Mol Biol Rep. 2012;39(4):3791-3797. doi: 10.1007/s11033-011-1156-9.

32. Oliveira CS, Saddi-Rosa P, Crispim F, Canani LH, Gerchman F, Giuffrida FM, et al. Association of ADIPOQ variants, total and high molecular weight adiponectin levels with coronary artery disease in diabetic and non-diabetic Brazilian subjects. J Diabetes Complications. 2012;26(2):94-98. doi: 10.1016/j.jdiacomp.2012.02.008.

33. Mofarrah M, Ziaee S, Pilehvar-Soltanahmadi Y, Zarghami F, Boroumand M, Zarghami N. Association of KALRN, ADIPOQ, and FTO gene polymorphism in type 2 diabetic patients with coronary artery disease: possible predisposing markers. Coron Artery Dis. 2016;27(6):490-496. doi: 10.1097/MCA.0000000000000386.

34. Mohammadzadeh G, Ghaffari MA, Heibar H, Bazyar M. Association of two Common Single Nucleotide Polymorphisms ( $+45 \mathrm{~T} / \mathrm{G}$ and $+276 \mathrm{G} / \mathrm{T})$ of ADIPOQ Gene with Coronary Artery Disease in Type 2 Diabetic Patients. Iran Biomed J. 2016;20(3):152-160. doi: 10.7508/ibj.2016.03.004.

35. Chirumbolo S. Single Nucleotide Polymorphism (SNP) in the Adiponectin Gene and Cardiovascular Disease. Iran Biomed J. 2016;20(3):187-188. doi: 10.7508/ibj.2016.04.001.

36. Tong $\mathrm{G}$, Wang $\mathrm{N}$, Leng $\mathrm{J}$, Tong $\mathrm{X}$, Shen $\mathrm{Y}$, Yang $\mathrm{J}$, et al. Common variants in adiponectin gene are associated with coronary artery disease and angiographical severity of coronary atherosclerosis in type 2 diabetes. Cardiovasc Diabetol. 2013;12:67. doi: $10.1186 / 1475-2840-12-67$.

37. Soccio T, Zhang YY, Bacci S, Mlynarski W, Placha G, Raggio G, et al. Common haplotypes at the adiponectin receptor 1 (ADIPOR1) locus are associated with increased risk of coronary artery disease in type 2 diabetes. Diabetes. 2006;55(10):2763-2770. doi: $10.2337 / \mathrm{db} 06-0613$. 
38. Jin Z, Pu L, Sun L, Chen W, Nan N, Li H, et al. Identification of susceptibility variants in ADIPOR1 gene associated with type 2 diabetes, coronary artery disease and the comorbidity of type 2 diabetes and coronary artery disease. PLoS One. 2014;9(6):e100339. doi: 10.1371/journal.pone.0100339.

39. Halvatsiotis I, Tsiotra PC, Ikonomidis I, Kollias A, Mitrou P, Maratou E, et al. Genetic variation in the adiponectin receptor 2 (ADIPOR2) gene is associated with coronary artery disease and increased ADIPOR2 expression in peripheral monocytes. Cardiovasc Diabetol. 2010 Feb 23;9:10. doi: 10.1186/1475-2840-9-10.

40. Liao YF, Chen LL, Zeng TS, Zheng J, Li HQ. Association of the +33371 A/G polymorphism in adiponectin receptor 2 gene with Type 2 diabetes in the Chinese population. J Endocrinol Invest. 2007;30(10):860-864. doi: 10.1007/BF03349228. 